
620 ON THE PROTEIN METABOLISM OF PRETERM INFANTS. P. Pencharz, L. Farri, A. Papageorgiou. (Spon: T. Heim) The Hospital for Sick Children, Toronto; and The Jewish General Hospital, Montreal, Quebec, Canada.

The effects of pooled mature human milk and two low protein formulae (whey or casein predominant) on the rates of whole body amino nitrogen flux $(Q)$, protein synthesis $(S)$ and breakdown (B) were studied in 30 preterm appropriate for gestational age infants, birth weights $1500-2000 \mathrm{~g}$. The infants were studied once they were receiving approximately $120 \mathrm{kcal} / \mathrm{kg} / \mathrm{d}$. Intakes of total nitrogen and energy were similar in all 3 groups as were nitrogen balances and length and weight growth.

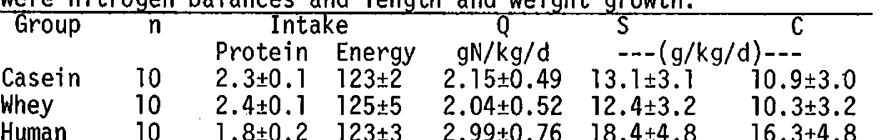

Rates of $Q, S$ and $C$ are aT1 significantly increased ( $p<0.074 .8$

in the human milk group. The only apparent explanation for this difference is the lower true protein intake $(p<0.01)$. These resuits suggest that preterm infants adapt metabolically to a lower protein intake by a more intense recycling of endogenous proteins and amino acids. Furthermore, the level of protein intake received by the breast fed group may approximate the lowest limit of protein requirement, as any further reduction would probably exceed the limits of metabolic adaptation.

\section{TROPHIC EFFECTS OF BOMBESIN AND SECRETIN ON NEONATAL} RAT PANCREAS. Paul F. Pollack and Travis E. Solomon. UCLA Center for the Heal th Sciences, Dept. of Pediatrics, and CURE-Wadsworth VA Hospita1, Los Angeles. (Spon. by Cynthia T. Barrett.

Secretin(SEC) and Bombesin(BNP) produce pancreatic hyperplasia and hypertrophy in adult rats. Their effects in newborn animals have not been studied. We investigated the effects of SEC and BNP on pancreatic growth at 2 postnatal ages. Neonatal rats were injected subcutaneously with BNP, $5 \mu \mathrm{g} / \mathrm{kg}$, or $S E C, 100 \mu \mathrm{g} / \mathrm{kg}$, or sal ine, every 12 hours for 7 days beginning at 6 or 13 days of age. Pups remained with their mothers until 12 hours after their last injection, when they were weighed and sacrificed. Weight gain did not differ among groups. Pancreatic weight, total DNA and protein (PRO) were measured and are shown below as ratios of treatment group values to control group. ${ }^{*} p<0.05, * * p<0.01 ; E=$ number in treatment group; $+=$ content per 100 gms. body weight; $+E=4$.

\begin{tabular}{|c|c|c|c|c|c|c|c|}
\hline 7) & $\begin{array}{l}1.05 \\
1.19\end{array}$ & $\begin{array}{l}\text { IDA } \\
1.06 \\
1.23\end{array}$ & $\begin{array}{l}\text { PR0 } \\
1.06 \\
1.38\end{array}$ & $\begin{array}{l}\text { PRO/DNA } \\
0.99 \\
1.13\end{array}$ & $\begin{array}{l}\text { Wt.t } \\
1.04 \\
1.18^{*}\end{array}$ & 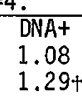 & $\begin{array}{l}\text { PROt } \\
1.10 * \\
1.39 * *\end{array}$ \\
\hline & & & & & & & 1 \\
\hline
\end{tabular}
1) SEC and BNP caused significant pancreatic hypertrophy at 13-20 days. Only SEC caused hypertrophy, and possibly hyperplasia at $6-13$ dáys, (2) Trophic effects of GI peptides may vary as a function of postnatal age,(3)BNP and SEC may play an important role in early pancreatic growth and development.

GIARDIASIS, MUCUS AND MALABSORPTION. A SCANNING (SEM) 622 AND TRANSMISSION (TEM) ELECTRON MICROSCOPIC STUDY OF SMALL BOWEL MUCOSA. J.Rainer Poley, Sheila Rosenfield and Albert W. Klein. Eastern Virginia Medical School, Departments of Pediatrics and Anatomy, Norfolk, Virginia, 23507.

Infestation with Giardia Lamblia (GL) may be associated with malabsorption, the pathogenesis of which continues to be under investigation. Recent observations in 2 children with giardiasis, including careful examination of biopsied small intestinal mucosa by SEM and TEM, has provided additional information, which may help to explain presence or absence of malabsorption. Two children, aged 2 and $2 \frac{1}{2}$ years with diarrhea of 3 to 4 months' duration underwent diagnostic workup, including small bowel biopsy. Stool examinations were negative, and serum immunoglobulins, and mucosal morphology by light microscopy normal in both. Biochemical indices indicated malabsorption in one of the children, but not in the other. SEM of the mucosa of the child with malabsorption showed that wide areas of villous surfaces were covered with sheets of mucus of variable thickness $(1.5-4.0 \mu)$. The microvilli were shortened. By contrast, the villous surfaces of the child without malabsorption were free of mucus, and most GL were trapped in mucus at the base of the villi. Mucosal invasion was not a major finding. These observations suggest that increased secre$t i o n$ (crypts) and deposition of mucus produces ail effective diffusion barrier to nutrients, explaining malabsorption phenomena and, possibly, subsequent adverse trophic effects on the mucosa. The proclivity to secrete mucus in response to the infestation with GL in humans may be determined genetically and/or environmentally.
623 FLUCTUATIONS IN THE RATE OF IV FLUTD ADMINISTRATION TO VERY LOW BIRTH WEIGHT (VLBW) INFANTS. Tonse N.K. Raju, Elizabeth Chow-Tung, Dharmapur1 V1dyasagar. University of Illinois, Department of Pediatrics, Chicago, Illinois.

Rapid blood volume expansion in VLBW infants has been suggested as a cause of ICH. We calculated, prospectively, hourly fluctuation in the rate $(\mathrm{m} 1 / \mathrm{kg} / \mathrm{day})$ of fluid actually revived in 10 acutely ill, VLBW (B.Wt. \& Gest. Age: $1.07 \pm 0.07 \mathrm{~kg}$ and $30 \pm 0.7$ wks), during the first 72 hours. Volume actually received were noted hour$1 y$, without nurses' knowledge. Fluctuations from ordered rate were calculated for 614 hours. Mean IV fluid ordered and actually recelved did not differ, however, wide hourly fluctuations in the rate occurred in all infants. Table gives \% of time fluctuation in rate of fluld actually received (expressed as $\mathrm{ml} / \mathrm{kg} / \mathrm{day}$ ) occurring in the study infants. During 614 hours only $4 \%$ of time infants got Fluct.rate $\pm 1-10 \mathrm{~m} 1 \quad \pm 11-30 \mathrm{~m} 1 \quad \pm 31-60 \mathrm{~m} 1 \quad \pm 61-90 \mathrm{~m} 1 \quad \pm 90 \mathrm{~m} 1$ $\mathrm{m} 1 / \mathrm{kg} / \mathrm{day}$

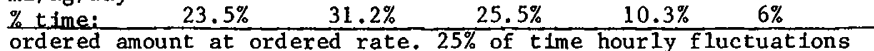
were $>50 \mathrm{~m} 1 / \mathrm{kg} / \mathrm{day}$. Excess and def $1 \mathrm{cit}$ rates were equal, thus total volume received was equal to ordered amount. Rap Id rates $>80$ $\mathrm{m} 1 / \mathrm{kg}$ occurred more of en in ICH infants (Stat.N.S.). Fluctuations were due to voltage variation $(10 \%)$, transfusion $(10 \%)$, inf 11 trations of IV and the 'adjustments' nurses make to make up ordered volume at the end of 8 hour shift. We conclude: a) Both fluid volume and rate actually recelved by the infant should be checked hourly in VLBW inf ants; b) These fluctuations may be responstble for hypo or hyperglycemia, appearance and disappearance of PDA murmurs and possi-

SERUM GASTRIN RESPONSE TO INTRAGASTRIC PROTEIN AND

624 CYSTEINE IN NEONATAL SWINE. Bradley M. Rodgers, Florida College of Medicine, Shands Teaching Ho Univers Departments of Surgery and Pediatrics, Gainesville, Florida.

Previous work has shown a decreased gastrin release in neonatal humans and swine in response to intragastric protein. To further study gastrin release in neonatal swine, serum gastrin determinations were made following intragastric instillation of protein and the amino acid cysteine, known to release antral gastrin in adult animals. Six animals, less than 48 hours of age, had catheters placed in the femoral and portal veins. In three animals, intragastric Sustagen $(1.7 \mathrm{gm}$ protein $/ \mathrm{kg})$ was followed by intragastric cysteine $(100 \mathrm{mM}, \mathrm{pH} 7.4$ at $10 \mathrm{cc} / \mathrm{kg})$, while three received cysteine. Simultaneous femoral and portal venous samples were analyzed for gastrin at $1,5,15,30,45$ and 60 minutes. The simultaneous femoral and portal vein gastrins did not differ statistically at any time. Basal gastrin was elevated in all animals when compared to adult values $(p<0.1)$. Following intragastric cysteine infusion, there was no significant elevation in gastrin in the portal ( 317 vs $264 \mathrm{pg} / \mathrm{ml}$ ) or femoral (253 vs 254 $\mathrm{pg} / \mathrm{m} 1$ ) veins. After protein challenge with Sustagen, there was a delayed, but significant, elevation in gastrin in portal and femoral samples at 30,45 and 60 minutes (386 vs $573 \mathrm{pg} / \mathrm{m} 1 \mathrm{P} . \mathrm{V}$. and 411 vs $569 \mathrm{pg} / \mathrm{ml}$ F.V.) $(\mathrm{p}<0.5)$. The results of these studies indicate a significant alteration in the release of gastrin. in response to intragastric amino acids in the neonatal swine when compared to adult animals.

RICKETS IN CHILDREN WITH CHOLESTATIC LIVER DISEASE:

625 EVALUATION AND TREATMENT. C.C. Roberts, L.S. BOok, G.M. Chan, and M.E. Matlak (Spon. by J.J. Herbst). Univ. of Utah, Dept. of Peds, and Surg. Salt Lake City, UT

Rickets, often leading to fractures and bone deformities, occurs in children with cholestatic liver disease (CLD) because of decreased intestinal absorption of minerals and impaired hepatic hydroxylation of vitamin $D$. The purpose of our investigation was to determine the frequency of rickets and its response to 1,25 $(\mathrm{OH})_{2}$ vitamin $\mathrm{D}$ therapy in 18 children with $\mathrm{CLO}$, ages 2 months to 5 years, over a two-year period. Serial measurements of bone mineral content were obtained using photon absorptiometry of the wrist and serum values of $25-\mathrm{OH}$ vitamin $\mathrm{D}$ and bilirubin measured on CLD patients receiving 400-1200 IU vitamin D by mouth. In 3 of 18 children bone mineral content (BMC) was normal for age. Al 1 had direct serum bilirubin $<2.0 \mathrm{mg} / \mathrm{d} 1$ and normal serum $25-\mathrm{OH}$ $D(N=10-40 \mathrm{ng} / \mathrm{ml})$. In 15 of $18 \mathrm{children} \mathrm{BMC}$ was $>2 \mathrm{SD}$ below the mean BMC of normal age-matched controls; serum 25-OH vitamin D was also low $(<10 \mathrm{ng} / \mathrm{ml})$. Once rickets was diagnosed, $12 \mathrm{pa-}$ tients received .05 to $.1 \mathrm{ug} / \mathrm{kg} /$ day $1,25(\mathrm{OH})$ vitamin $\mathrm{D}$. Eight of 12 children treated with $1,25(\mathrm{OH})_{2}$ vitamin $\mathrm{D}$ had improvement of bone disease indicated by a doubling of the BMC and an increase in the $\mathrm{BMC} / \mathrm{body}$-weight ratio to the normal range. Conclusion: Metabolic bone disease is common in children with CLD. Photon absorptiometry is a simple and accurate technique for identifying and monitoring children with hepatic rickets. In children with CLD oral $1,25(\mathrm{OH})_{2}$ vitamin 0 may be effective for the treatment of hepatic rickets? 